\title{
Lung tissue volume estimated by simultaneous radiographic and helium dilution methods
}

\author{
JD ARMSTRONG, EH GLUCK, RO CRAPO, HAZEL A JONES, JMB HUGHES
}

From the Departments of Diagnostic Radiology and Pulmonary Medicine, University of Utah College of Medicine, Salt Lake City, Utah 84132; and the Department of Medicine, Royal Postgraduate Medical School, London

ABSTRACT The pulmonary total tissue volume (blood, extravascular water, and dry tissue vol-

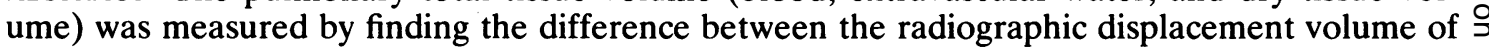
the thorax $\left(\mathrm{RDV}_{\mathrm{T}}\right)$ and the lung gas volume. Simultaneous determinations of $\mathrm{RDV}_{\mathrm{T}}$ and gas $\overrightarrow{\mathrm{c}}$ volume were made in 10 healthy subjects sitting upright. $\mathrm{RDV}_{\mathrm{T}}$ was determined from posteroan- $\frac{\mathbb{D}}{\mathrm{O}}$ terior and lateral chest radiographs, a computerised modification of the Barnhard method being $\overrightarrow{\mathbb{D}}$ used; and gas volume was measured by helium dilution with each radiographic exposure. At $\frac{3}{0}$ functional residual capacity pulmonary total tissue volume was $843 \pm 110 \mathrm{ml}(1 \mathrm{SD})$. The density $\stackrel{\mathbb{D}}{-}$ of the lung ( $\mathrm{ml}$ tissue per $\mathrm{ml}$ tissue and gas) was $0.19 \pm 0.03$ (1 SD). This method, different in $\vec{\oplus}$ principle from indicator-dilution and acetylene rebreathing studies, provides measurements of $\stackrel{\infty}{\sim}$ total tissue volume.

The measurement of lung tissue volume adds quantitative information to the diagnosis and assessment of the response to treatment in patients with increased extravascular lung water. So far complex techniques such as double indicator dilution, ${ }^{12}$ thermodilution, ${ }^{3}$ or acetylene detection with a respiratory mass spectrometer ${ }^{4-7}$ have been used. These methods have not been widely applied. Alternatively, pulmonary total tissue volume could be estimated on the basis of the difference between the radiographic displacement volume of the thorax $\left(\mathrm{RDV}_{\mathrm{T}}\right)$ and alveolar gas volume $\left(\mathrm{V}_{\mathrm{A}}\right)$ by helium rebreathing or by plethysmography. ${ }^{8}$ Radiographic displacement volume determined by the modified Barnhard technique 9 has been validated against helium dilution and body plethysmography. ${ }^{10}$ This technique can be done by hand or with a simple computer, and so requires minimal software. It could also be applied at the bedside by the use of portable radiographs after correction for magnification. Simultaneously lung volume could be measured with the patient rebreathing from an anaesthetic bag. In this study simultaneous measurements of alveolar gas volume and radiographic displacement volume $\left(\mathrm{RDV}_{\mathrm{T}}\right)$ were made to establ-

Address for reprint requests: Dr JMB Hughes, Department of Medicine, Royal Postgraduate Medical School, Hammersmith Hospital, London W12 0HS. ish normal values in the erect posture for total tissue volume $\left(\mathrm{V}_{\mathrm{TT}}\right)$.

\section{Methods}

The subjects were selected from university staff. All were healthy and without evidence of cardiopulmonary disease, and only one subject had a history of smoking. Informed consent was obtained. Each sub- 음 ject was comfortably seated on a stool, mounted on $\underset{x}{0}$ a moveable platform in front of a standard chest $\frac{5}{3}$ radiographic unit. An anaesthesia bag was filled from a calibrated syringe with two litres of a dry $10 \%$ helium-in-oxygen mixture, and a three-way valve (dead space $14 \mathrm{ml}$ ) was attached. The subject 윽 breathed quietly with the valve open to room air. On $\supset$ reaching end expiration he held his breath and signalled. The valve was then opened to the anaes- $N$ thesia bag and a standard posteroanterior chest radiograph was taken. The subject then rebreathed $\tilde{N}$ the helium gas mixture six times, emptying the $\underset{\omega}{\mathrm{N}}$ anaesthesia bag with each breath. A previous study using a mass spectrometer had shown that equilib-o

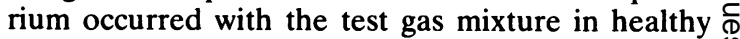
individuals within six breaths. The rebreathed gas ? was passed through soda lime to remove carbon 0 dioxide and was subsequently analysed for helium. The final helium concentration was corrected for the $\stackrel{\mathbb{Q}}{\square}$ carbon dioxide absorbed (a value of $5 \%$ was taken $\stackrel{\mathbb{Q}}{\square}$ on the basis of earlier measurements). Thoracic gas $\overline{0}$ 676 
volume was calculated and converted from ATPD to BTPS. An estimated dead space from the mouth to the carina $(100 \mathrm{ml})^{11}$ was subtracted from the final helium dilution lung volume because this part of the upper airway was not included in the radiographic volume. Thus the final volume estimate summed the alveolar volume and the volume of the anatomical dead space beyond the carina (about $50 \mathrm{ml}$ ). The same procedure was followed with the subject in position for the lateral chest radiograph.

Chest radiographs were obtained with a General Electric MS1-850 generator (1.5-mm focal spot and 3-metre tube-film distance), $140-\mathrm{kV}$ phototimed exposures and a 12-to-1 grid being used. To minimise radiation exposure green light-sensitive radiographic film and intensifying screens were used. The magnification on the radiographs was determined by placing a coin of known diameter in the subject's mid-axillary line. This diameter was measured on the radiograph and the ratio of the two (radiographic:absolute) was used to calculate magnification. All measurements necessary for the calculation of $\mathrm{RDV}_{\mathrm{T}}$ were reduced by this factor. $\mathrm{RDV}_{\mathrm{T}}$ was measured by the technique of Barnhard, ${ }^{9}$ the same computer and technique as modified by Barrett $^{10}$ being used. Barnhard's method, ${ }^{9}$ as described, was designed to be used at total lung capacity; nevertheless, computed tomography has shown (in supine subjects) that there is little change in the shape of the chest over the full range of vital capacity. ${ }^{8} \mathrm{RDV}_{\mathrm{T}}$ was measured in triplicate by one observer and mean values were used. The results of the helium dilution lung volume $\left(\mathrm{V}_{\mathrm{He}}\right)$ obtained during the posteroanterior and lateral views were averaged. The difference between the $\mathrm{RDV}_{\mathrm{T}}$ and helium dilution lung volume was recorded as total tissue volume $\left(\mathrm{V}_{\mathrm{TT}}\right)$. The ratio of $\mathrm{V}_{\mathrm{TT}}$ to $\mathrm{RDV} \mathrm{V}_{\mathrm{T}}$ was expressed as the specific tissue volume (STV).

\section{Results}

Anthropomorphic data and radiographic and helium lung volumes are set out in the table. The average $\mathrm{V}_{\mathrm{TT}}$ for 10 normal subjects was $0 \cdot 843 \pm 0 \cdot 110$ (1 $\mathrm{SD})$ litres; $\mathrm{V}_{\mathrm{TT}}$ per unit thoracic volume $\left(\mathrm{RDV}_{\mathrm{T}}\right)$ that is, specific tissue volume (STV) or lung density ( $\mathrm{ml}$ of tissue per $\mathrm{ml}$ of lung tissue and gas)averaged $0 \cdot 19 \pm 0.03$ (table).

\section{Discussion}

Methods for measuring the radiographic volume of the lungs are well established. ${ }^{910}$ Barnhard, ${ }^{9}$ for example, equates the lungs with a stack of cylindrical ellipsoids. The dimensions of these ellipsoids are obtained by tracing around the lung in posteroanterior and lateral views and dividing the vertical height into 500 slices. ${ }^{10}$ The gas volume is derived by subtracting from the total $(a)$ the volume of the heart and subphrenic spaces and (b) an estimate of tissue, blood, and extravascular water volumes. ${ }^{910}$ The correlations ( $r$ ) in normal subjects between radiographic and plethysmographic and between radiographic and helium dilution estimates of total lung capacity range from 0.85 to $0.88 .9^{1012}$

Pierce and co-workers, ${ }^{8}$ using slightly different measuring and mathematical techniques, found that the difference between the radiographic lung volume (without the correction $(b)$ for tissue volume) and the plethysmographic volume in 35 normal subjects averaged $0.72 \mathrm{l}$. Both measurements were made at total lung capacity. They pointed out that this difference represented lung tissue volume-that is, blood in capillary, arterial, and venous vessels, and extravascular tissues (cells, lymph, free water, and gel). Their technique was different in some respects. The radiographic and plethysmographic

Anthropometric data, radiographic displacement volume of the thorax $\left(R D V_{T}\right)$, helium dilution lung volume $\left(V_{H e}\right)$, total tissue volume of lung $\left(V_{T T}\right)^{*}$ (all in litres), and tissue volume per unit thoracic volume $\left(V_{T T} / R D V_{T}\right)$ in all the subjects studied

\begin{tabular}{|c|c|c|c|c|c|c|c|}
\hline Subject & Height $(m)$ & Weight $(\mathrm{kg})$ & Age (y) & $R D V_{T}(l) \div$ & $V_{H e}(l) \ddagger$ & $V_{T T}(l)$ & $V_{T T^{\prime}} R D V_{T}$ \\
\hline $\begin{array}{r}1 \\
2 \\
3 \\
4 \\
5 \\
6 \\
7 \\
8 \\
9 \\
10\end{array}$ & $\begin{array}{l}1 \cdot 65 \\
1.75 \\
1.83 \\
1.75 \\
1.78 \\
1.83 \\
1.90 \\
1.78 \\
1.80 \\
1 \cdot 80\end{array}$ & $\begin{array}{l}50 \\
75 \\
77 \\
70 \\
88 \\
68 \\
89 \\
70 \\
73 \\
86\end{array}$ & $\begin{array}{l}41 \\
43 \\
28 \\
29 \\
27 \\
33 \\
30 \\
28 \\
32 \\
31\end{array}$ & $\begin{array}{l}4.49 \pm 0.1 \\
4.75 \pm 0.1 \\
4.44 \pm 0.037 \\
4.26 \pm 0.034 \\
3.88 \pm 0.031 \\
5.40 \pm 0.081 \\
3.8 \pm 0.037 \\
4.38 \pm 0.092 \\
4.63 \pm 0.051 \\
4.48 \pm 0.012\end{array}$ & $\begin{array}{l}3 \cdot 55 \\
4 \cdot 0 \\
3 \cdot 8 \\
3 \cdot 43 \\
3 \cdot 10 \\
4 \cdot 53 \\
2 \cdot 84 \\
3 \cdot 48 \\
3 \cdot 64 \\
3 \cdot 71\end{array}$ & $\begin{array}{l}0.94 \\
0.75 \\
0.64 \\
0.83 \\
0.78 \\
0.87 \\
0.96 \\
0.90 \\
0.99 \\
0.77\end{array}$ & $\begin{array}{l}0.21 \\
0 \cdot 16 \\
0 \cdot 14 \\
0.19 \\
0.20 \\
0 \cdot 16 \\
0.25 \\
0.21 \\
0.21 \\
0.17\end{array}$ \\
\hline $\begin{array}{l}\text { Mean } \\
( \pm 1 \mathrm{SD})\end{array}$ & 1.79 & $74 \cdot 6$ & 32 & $\begin{array}{r}4.45 \\
\pm 0.45\end{array}$ & $\begin{array}{r}3.61 \\
\pm 0.47\end{array}$ & $\begin{array}{r}0.843 \\
\pm 0.110\end{array}$ & $\begin{array}{r}0.19 \\
\pm 0.03\end{array}$ \\
\hline
\end{tabular}

* $\mathrm{V}_{\mathrm{TT}}=\mathrm{RDV}_{\mathrm{T}}$ minus $\mathrm{V}_{\mathrm{He}}$.

+ Mean \pm 1 SD of three or four measurements.

$\ddagger$ Mean of measurements during posteroanterior and lateral radiographic exposures. 
measurements were made sequentially, not simultaneously, and in different postures-standing for the former and sitting for the latter. In addition, there were three correction factors, averaging $145 \mathrm{ml}$ each, to take account of the posture difference, abdominal gas compression, and a radiographic error.

The technique reported here is similar in principle to that of Pierce and associates ${ }^{8}$ but the radiographic and gas volume measurements were made simultaneously, each radiograph being accompanied by a gas dilution estimate of lung volume; the difference between the gas volume measurements for the posteroanterior and lateral radiographs averaged 0.211 (range $0-0 \cdot 51$ ). The use of a lower lung volume (functional residual capacity) meant that the derived volume $\left(\mathrm{V}_{\mathrm{TT}}\right)$ formed a larger fraction $(0 \cdot 19)$ of the radiographic volume and increased the signal-tonoise ratio. But the disadvantage of this method is that helium equilibration is required. While this presents no problem in normal subjects, in patients with airflow obstruction and maldistribution of ventilation the helium volume would be too low and the total tissue volume overestimated. In these cases a steady-state helium equilibration technique could be adopted. Nevertheless, patients with uncomplicated heart failure, diffuse interstitial processes, and the adult respiratory distress syndrome could be studied with the simpler method described here.

Clearly, the technique makes great demands on the accuracy with which the radiographic and gas volumes can be defined. The reproducibility in locating the landmarks on the radiographs necessary for the calculation of lung volumes is set out in the table. The measurements on the radiograph were made three times and $\mathrm{RDV}_{\mathrm{T}}$ calculated as the mean of three estimations. The overall coefficient of variation was $1.3 \%$. The difference between the helium dilution estimates on the posteroanterior and lateral radiographs was also small, being $5.5 \%$ of the mean value. The standard deviation of the estimates of total tissue volume was $110 \mathrm{ml}$, a coefficient of variation of $13 \%$. Mean lung density in this series (specific tissue volume) was $0 \cdot 19$ with a coefficient of variation of $16 \%$; if we exclude subject 7 (clearly his volumes per unit height are much lower than those for all the others, presumably because the measurements were made below his true functional residual capacity) the variation of density (as a fraction of that of water) was only $7 \%(0 \cdot 14-0 \cdot 21)$.

Further work will be required to assess the reproducibility and sensitivity of this technique in detecting an abnormal tissue volume. A second set of radiographs was not considered justified in normal subjects, but serial measurements are planned in patients for whom chest radiographs are clinically indicated. For example, a patient with miliary tuberculosis had a total tissue volume of $1600 \mathrm{ml}$, which fell after treatment to $930 \mathrm{ml}$ as the disease resolved clinically and radiographically.

It is interesting to compare lung tissue volumes $\stackrel{\odot}{\circ}$ measured by different methods. Lung dry weight क from postmortem studies ${ }^{13}$ is $95 \mathrm{ml}$; extravascular $\vec{\circ}$ water is $385 \mathrm{ml}, 2$ and lung blood volume (a $25 \%$ fall because of the erect posture being allowed for ${ }^{14}$ ) is $\vec{\omega}$ about $350 \pm 50 \mathrm{ml}$. Total tissue volume is around $830 \pm 50 \mathrm{ml}$. This agrees well with the radiographic $\vec{x}$ estimates in this study $(843 \mathrm{ml})$. The tissue volume measured with acetylene inhalation ${ }^{4-715}$ averages 0 $600 \mathrm{ml}$, which is $250 \mathrm{ml}$ less than the total tissue $\stackrel{\text { J }}{ }$ volume, presumably owing to exclusion of blood in $\%$

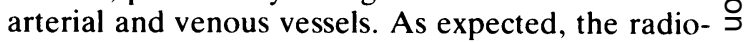
graphic estimates are greater than those measured $\vec{c}$ with acetylene. In the supine posture predicted total $\mathbb{D}$ tissue volume will increase by $100-845 \mathrm{ml}$ because $\frac{\mathrm{T}}{\mathbb{\mathrm { T }}}$ of an increase in pulmonary blood volume. ${ }^{14}$

We thank Jacqueline Pennock (Hammersmith Hospital), Edwin N Nakashima, Anne Wallace, and $\stackrel{\bullet}{\varnothing}$ Bruce Mortensen for technical assistance.

\section{References}

' Chinard FP. Estimation of extravascular lung water by indicator-dilution techniques. Circulation Res $\overrightarrow{\overline{0}}$ 1975;37:137-45

${ }^{2}$ Pistolesi M, Giuntini C. Assessment of extravascular lung water. Radiol Clin NA 1978;16:551-74.

${ }^{3}$ Noble WH, Kay JC, Maret KH, Caskanett G. Reappraisal of extravascular lung thermal volume as a measure of pulmonary edema. J Appl Physiol: Respirat Environ Exercise Physiol 1980;48:120-9.

${ }^{4}$ Farney FJ, Morris AH, Gardner RM, Armstrong JD. O Rebreathing pulmonary capillary and tissue volume in normals after saline infusion. J Appl Physiol: Respir: Environ: Exercise Physiol 1977;43:246-53.

${ }^{5}$ Rose GL, Cassidy SS, Johnson RL jun. Diffusing capacity 0 at different lung volumes during breath-holding and rebreathing. J Appl Physiol: Respirat Environ Exercise Physiol 1979;47:32-7.

- Sackner MA, Greeneltch D, Heinman MS, Epstein S, N Atkins N. Diffusing capacity, membrane diffusing capacity, capillary blood volume, pulmonary tissue $\mathrm{N}$ volume, and cardiac output measured by a rebreathing technique. Am Rev Respir Dis 1975;111:157-65.

7 Severinghaus W, Ozanne GM, Louderbough HG, Overland ES, Stafford MJ. Lung water and cardiac output

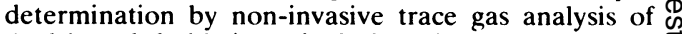
dual breath-holds in a single breath. In: Matthys $\mathrm{H}$, ed. Respiration research. Vol 11. Biomedical engineering and data processing in pneumology. Basel: Karger, 1979: 280-6.

${ }^{8}$ Pierce RJ, Brown DJ, Holmes M, Cumming G, Denison DM. The estimation of lung volumes from chest 
radiographs using shape information. Thorax 1979;34:726-34.

${ }^{9}$ Barnhard HF, Pierce JA, Joyce JN, Bates JH. Roentgenographic determination of total lung capacity. Am J Med 1960;28:51-60.

${ }^{10}$ Barrett NA, Clayton TD, Lambson CR, Morris AH. Computerized roentgenographic determination of total lung capacity. Am Rev Respir Dis 1976;113:239-44.

" Nunn JF, Campbell EJM, Peckett BW. Anatomical subdivisions of the volume of respiratory dead space and effect of position of the jaw. J Appl Physiol
1959;14:174-6.

12 Nicklaus TM, Watanabe S, Mitchell MM, Renzetti AD. Roentgenologic, physiologic and structural estimation of the total lung capacity in normal and emphysematous subjects. Am J Med 1967;42:547-53.

${ }^{13}$ Staub NC. Pulmonary edema. Physiol Rev 1974;54:678-811.

${ }^{14}$ Harris P, Heath D. The human pulmonary circulation. 2nd ed. Edinburgh: Churchill Livingstone, 1977:163.

15 Cander L, Forster RE. Determination of pulmonary parenchymal tissue volume and pulmonary capillary blood flow in man. J Appl Physiol 1959;14:541-51. 